\title{
Evaluation of remodeling in left and right ventricular myocytes from heterozygous (mRen2)27 transgenic rats
}

\author{
Christophe Chouabe ${ }^{1}$, Estelle Ricci ${ }^{1}$, Mazen $\mathrm{Kurdi}^{2}$, Claude Legrand ${ }^{1}$, Giampiero Bricca ${ }^{2}$ \\ and Robert Bonvallet ${ }^{1}$ \\ ${ }^{1}$ CNRS UMR 5123, Physiologie des Régulations Energétiques, Cellulaires et Moléculaires, Campus de la Doua, Université de \\ Lyon 1, 69622 Villeurbanne, France \\ 2 EA 4173, Agressions Vasculaires et Réponses Tissulaires, Campus Laënnec, Université de Lyon, 69622 Lyon, France
}

\begin{abstract}
Cardiac remodeling was assessed both in the pressure-overloaded left ventricle and in the normotensive right ventricle of hypertensive transgenic rats (mRen2)27 (TGR27). The present study combined histology, electrophysiology, molecular biology and biochemistry techniques. A significant increase in action potential (AP) duration was recorded both in right and left ventricular myocytes wheareas only in the latter ones were hypertrophic. The increase in AP duration is mainly supported by the reduction of the transient outward $\mathrm{K}$ current $\left(\mathrm{I}_{\mathrm{to}}\right)$ density since no significant modification was observed for the L-type calcium current $\left(\mathrm{I}_{\mathrm{Ca}, \mathrm{L}}\right)$, the sodium-calcium exchange current $\left(\mathrm{I}_{\mathrm{NCX}}\right)$, the delayed rectifier current $\left(\mathrm{I}_{\mathrm{K}}\right)$ and the inward rectifier current $\left(\mathrm{I}_{\mathrm{K} 1}\right)$. The lower amplitude of $\mathrm{I}_{\mathrm{to}}$ current was associated with a lower Kv4.3 protein expression both in right and left ventricles while Kv4.3 mRNA levels was decreased only in left ventricle. Thus, a differential ventricular remodeling takes place in the TGR27 model. The possible cause of electrical remodeling in right ventricular myocytes of TGR27 is discussed.
\end{abstract}

Key words: K channel - Left ventricular hypertrophy - L-type calcium current - Sodium-calcium exchange current - Transient outward K current

\section{Introduction}

Arterial systemic hypertension is the most common cause of left ventricular pressure overload. This overload can induce ventricular hypertrophy as part of cardiac remodeling. Cardiac hypertrophy is associated with an increased incidence of sudden death and susceptibility to proarrhythmic effects of antiarrhythmic agents attributed to the presence of increased dispersion of ventricular repolarization (Kozhevnikov et al. 2002). Not surprisingly, a lot of effort has been invested to characterize the mechanisms underlying the electrical remodeling in cardiac hypertrophy. This knowledge may improve the way antiarrhythmic agents are used or lead to the development of better ones (Hill 2003).

Correspondence to: Robert Bonvallet, CNRS UMR 5123, Physiologie des Régulations Energétiques, Cellulaires et Moléculaires, Campus de la Doua, Université de Lyon 1, 69622 Villeurbanne, France E-mail: Robert.Bonvallet@univ-lyon1.fr
An animal model widely used to study pathophysiological alterations in hypertensive heart disease is the spontaneous hypertensive rat (SHR). This model represents a suitable and predictive model to understand the cellular electrophysiological alterations during hypertrophy (Cerbai et al. 2000). In contrast to the polygenic cause of hypertension in SHR, hypertensive transgenic rats (mRen2)27 (TGR27) expressing the murine Ren 2 renin gene are a well-established monogenic model of severe arterial systemic hypertension (Mullins et al. 1990; Engler et al. 1998 for a review). The transgene is highly expressed in various tissues, increasing the tissue renin activity and decreasing renal renin gene expression (Zhao et al. 1993). Pathomorphological alterations of cardiovascular organs such as hypertrophy of the heart are already observed in young rats aged $<12$ weeks (Bachmann et al. 1992). To date no cardiac cellular electrophysiological studies were ever performed on this model.

The exact molecular mechanisms that trigger cardiac electrical remodeling are not fully understood (Wolk 2003). However, association between ventricular hypertrophy and 
the electrical changes has been established for a long time. This can explain why a vast majority of electrophysiological studies were only performed on the ventricular part subjected to pressure overload (Hart 1994; Hill 2003).

The TGR27 model is mainly considered as a model of overexpressed adrenal renin-angiotensine-aldosterone systems (RAAS). Overactive tissue RAAS, and not pressure overload, has been demonstrated to be primarily responsible for cardiac hypertrophy in this rat strain (Pachori et al. 2002). As overactive RAAS is likely present in all cardiac tissues, we examined the cardiac remodeling (at morphological, electrophysiological and molecular levels) not only in the pressure-overloaded left ventricle but also in the right. We report a significant increase in AP duration both in right and left ventricular myocytes while hypertrophy was detected only in the latter ones. The increase in action potential (AP) duration is supported mainly by a reduction of the transient outward $\mathrm{K}$ current $\left(\mathrm{I}_{\mathrm{to}}\right)$ density since no significant modification was observed in densities of L-type calcium current $\left(\mathrm{I}_{\mathrm{Ca}, \mathrm{L}}\right)$, sodium-calcium exchange current $\left(\mathrm{I}_{\mathrm{NCX}}\right)$, delayed rectifier current $\left(\mathrm{I}_{\mathrm{K}}\right)$ and inward rectifier current $\left(\mathrm{I}_{\mathrm{K} 1}\right)$. The lower amplitude of $\mathrm{I}_{\mathrm{to}}$ current was associated with a lower Kv4.3 protein expression both in right and left ventricles while the amount Kv4.3 mRNA was decreased only in left ventricle. The present work shows a differential remodeling between the ventricles of TGR27 model, with only an electrical remodeling in the right ventricle whereas left ventricle undergoes both structural and electrical remodeling.

\section{Materials and Methods}

\section{Transgenic animal models and controls}

The experiments were carried out following the "European Convention for the Protection of Vertebrate Animals used for Experiments and other Scientific Purposes" (Council of Europe No. 123, Strasbourg, 1985). Male 10-week-old rats were used for all experiments. The animals were held on a standard laboratory animal diet and tap water ad libitum. They were exposed to a 12 -h light/dark cycle. Heterozygous TGR27 ( $n=24)$ were obtained from our own colony by crossbreeding transgene positive males with non-transgenic females. The littermates were tested for the presence of the transgene and negative animals were used as controls (CTR; $n=22$ ). Heterozygous animals were chosen because their hypertension reaches values up to $240 \mathrm{~mm} \mathrm{Hg}$ at 8-9 week and only males were used because they have higher blood pressures than females (Lee et al. 1996).

\section{Histological study}

Ventricular wall thickness was measured as previously described (Chouabe et al. 2002). Briefly, after aortic retrograde perfusion of the heart, 2-mm-thick transversal ventricular slices were cut with a vibratome, dehydrated, and embedded in resin. Measurements of ventricular wall thickness were done on the slices.

\section{Isolation of ventricular myocytes and electrophysiological measurements}

Isolated ventricular myocytes were obtained by enzymatic digestion of perfused hearts, as previously described (Chouabe et al. 1997). At the end of the digestion, right, left sub-epicardial and left sub-endocardial ventricular free walls were carefully dissected. Each ventricular portion was separately cut off and gently stirred in low-Ca, high-K solution in order to obtain myocytes. Myocytes were kept in this storage solution at $4^{\circ} \mathrm{C}$ for at least $2 \mathrm{~h}$. The dimensions of freshly dissociated myocytes were assessed by measuring length and width with a graticule mounted on the lens of a microscope. Due to the fact that left ventricular free wall was dissected in an endo- and an epimyocardial layer, we cannot exclude a potential contamination with tissue originating from the midmyocardial region that contains approximately $60 \%$ of the ventricular myocytes (Smith 2007).

Ionic currents and APs were recorded in the conventional whole-cell patch-clamp configuration, with an RK400 amplifier (Biologic, Claix, France), at room temperature $\left(20-23^{\circ} \mathrm{C}\right)$. Patch pipettes had resistances of $1-3 \mathrm{M} \Omega$ when filled with pipette solution (see below). Voltage recordings were not corrected for the liquid junction potentials (range, $18-20 \mathrm{mV}$ for pipette solution vs. control solution). For recording, myocytes were placed in a plastic Petri dish containing the appropriate extracellular medium (see below), and were continuously superfused with solutions flowing by gravity from a set of five capillaries connected to a single outlet. Superfusion flow rate was $20-40 \mu \mathrm{l} / \mathrm{s}$.

Membrane capacitance was systematically measured and was calculated by analysing the capacitive surge produced by a small voltage step as described previously (Chouabe et al. 1997). The series resistance ranged from 3 to $4 \mathrm{M} \Omega$ and was compensated by $60-80 \%$. Voltage-clamp protocols will be described in the Results section. The measurement of $\mathrm{I}_{\mathrm{NCX}}$ was made as described by Espinosa et al. (2000). The kinetics of $\mathrm{I}_{\mathrm{to}}$ and $\mathrm{I}_{\mathrm{Ca}, \mathrm{L}}$ currents and the voltage dependence of steady-state activation and inactivation were determined as described previously (Chouabe et al. 1997).

\section{Solutions and drugs}

For AP recording, the internal solution in the patch electrode contained (mmol/l): $\mathrm{NaCl} 7, \mathrm{KCl} 30, \mathrm{~K}$-aspartate 110, $\mathrm{MgCl}_{2}$ 2, EGTA/KOH 0.2, HEPES/KOH 10, $\mathrm{pH}=7.2$ and the external solution contained (mmol/l): $\mathrm{NaCl} 140, \mathrm{KCl} 5, \mathrm{CaCl}_{2}$ 2.5, $\mathrm{MgCl}_{2}$ 2, glucose 10, HEPES/ $\mathrm{NaOH} 10, \mathrm{pH}=7.4$. 
For $\mathrm{I}_{\mathrm{to}}, \mathrm{I}_{\mathrm{K} 1}$ and $\mathrm{I}_{\mathrm{K}}$ recordings, the internal solution in the patch electrode contained ( $\mathrm{mmol} / \mathrm{l}): \mathrm{K}$-aspartate 130 , $\mathrm{KCl} 5, \mathrm{MgCl}_{2}$, glucose 10, $\mathrm{K}_{2}$-ATP 3, $\mathrm{Na}_{2}$-CP 5, $\mathrm{Na}_{3}$-GTP 0.4, EGTA/KOH 5, HEPES/KOH 10, $\mathrm{pH}=7.2$ and the external solution contained (mmol/l): choline- $\mathrm{Cl} 135, \mathrm{MgCl}_{2}$ $1.1, \mathrm{CaCl}_{2} 2.5, \mathrm{CdCl}_{2} 0.5$, glucose 10 , atropine-sulfate 0.01 , $\mathrm{HEPES} / \mathrm{KOH} 10, \mathrm{pH}=7.4$.

For $\mathrm{I}_{\mathrm{Ca}, \mathrm{L}}$ recording, the internal solution in the patch electrode contained (mmol/l): Cs-aspartate $120, \mathrm{MgCl}_{2} 5$, glucose 5, $\mathrm{K}_{2}$-ATP 3, $\mathrm{Na}_{2}$-CP 5, $\mathrm{Na}_{3}$-GTP 0.4, EGTA/CsOH 5, $\mathrm{HEPES} / \mathrm{CsOH} 10, \mathrm{pH}=7.2$ and the external solution contained (mmol/l): TEA-Cl 145, $\mathrm{MgCl}_{2} 1.1, \mathrm{CaCl}_{2} 2.5$, glucose 10, 4-aminopyridine 3, HEPES/CsOH 10, $\mathrm{pH}=7.4$.

For $\mathrm{I}_{\mathrm{NCX}}$ recording, the internal solution in the patch electrode contained (mmol/l): $\mathrm{NaCl} 7$, Cs-aspartate 100, $\mathrm{MgCl}_{2}$ 1.1, EGTA/CsOH 0.2, HEPES/CsOH 5, $\mathrm{pH}=7.4$ and the external solution contained ( $\mathrm{mmol} / \mathrm{l}): \mathrm{NaCl}$ (or LiCL) 140, $\mathrm{CsCl} 5, \mathrm{CaCl}_{2} 2.5, \mathrm{MgCl}_{2}$ 2, glucose 10, HEPES/NaOH (or $\mathrm{LiOH}$ ) $5, \mathrm{pH}=7.4$.

\section{Measurements of mRNA levels of K channels}

Total RNA was extracted from right and left (sub-epicardial and sub-endocardial) ventricular free walls using Trizol Reagent (Invitrogen, Carlsbad, CA, USA) and treated with DNase (Deoxyribonuclease I, amplification grade, Invitrogen), according to the manufacturer's instructions. Quality and concentration of total RNA were assessed by capillary electrophoresis (RNA 6000 Nano Assay; Agilent Technologies, Massy, France). Total RNA was transcribed to cDNA using Superscript II reverse transcriptase (Invitrogen) and random hexamers (pdN6-Amersham Pharmacia Biotech, Piscataway, NJ, USA). The cDNA samples were subjected to PCR amplification using Platinum taq DNA Polymerase (Invitrogen). PCR was carried out using a thermal cycler (Biometra ${ }^{\circledR}$ T-Gradient thermoblock, Göttingen, Germany).

The mRNA levels corresponding to the a subunits of the K channels (Kv1.4, Kv4.2, Kv4.3 and Kv2.1) were studied and simultaneously measured in paired samples from CTR and TGR27. Specific primers, annealing temperature and the size of amplified products are shown in Table 1 . The number of cycles (varying from 20 to 35 ) used to amplify each cDNA was set up to allow the PCR to proceed in a linear range. All ventricular samples, from CTR and TGR27, were submitted to reverse transcription, followed by PCR as previously described by Kurdi et al. (2005). PCR amplification was conducted simultaneously for all paired samples at two different cycle numbers. Amplification product was loaded onto a 1.5\% agarose gel stained with ethidium bromide. The density of each PCR band was measured and analysed by Kodac Digital Science 1D software. In TGR27 and CTR, cDNA were measured at the same PCR cycle number and the amount of mRNA was expressed as the ratio to $18 \mathrm{~S}$ rRNA product, taken as internal control and expressed in arbitrary units.

\section{Protein extraction and Western blot analysis}

Extracts of right and left (sub-epicardial and sub-endocardial) ventricular homogenates from CTR and TGR27 were prepared from frozen tissue (liquid nitrogen) using the Compartmental Protein Extraction Kit (Upstate).

Table 1. Oligonucleotide primer pairs for reverse transcription-PCR

\begin{tabular}{|c|c|c|c|c|c|c|}
\hline Gene & $\begin{array}{c}\text { Accession } \\
\text { number }\end{array}$ & Primer & Sequence & $\begin{array}{l}\text { Size } \\
\text { (bp) }\end{array}$ & $\begin{array}{c}\text { Hybridation } \\
\text { temperature }\left({ }^{\circ} \mathrm{C}\right)\end{array}$ & $\begin{array}{c}\text { Amplicon size } \\
(\mathrm{bp})\end{array}$ \\
\hline Kv1.4 & X16002 & $\begin{array}{l}\mathrm{F} \\
\mathrm{R}\end{array}$ & $\begin{array}{l}\text { 5’ TGTGTCTGGTCTACGCTTCG 3’' } \\
\text { 5’ AGAATGACCAGGACCGACAC 3' }\end{array}$ & 20 & 60 & 199 \\
\hline $\mathrm{Kv} 4.2$ & M59980 & $\begin{array}{l}\mathrm{F} \\
\mathrm{R}\end{array}$ & $\begin{array}{l}\text { 5’ CTCAGGACGCTCTAATTGTG 3’ } \\
\text { 5’ ACTCCTCATAACAGCAGTCG 3' }\end{array}$ & 20 & 60 & 296 \\
\hline $\mathrm{Kv} 4.3$ & U75448 & $\begin{array}{l}\mathrm{F} \\
\mathrm{R}\end{array}$ & $\begin{array}{l}\text { 5’ GATGAGCTGGCCTTCTATGG 3’' } \\
\text { 5’ GTGTCCAGGCAGAAGAAAGC 3’ }\end{array}$ & 20 & 60 & 347 \\
\hline $\mathrm{Kv} 2.1$ & X16476 & $\begin{array}{l}\mathrm{F} \\
\mathrm{R}\end{array}$ & $\begin{array}{l}\text { 5' CTCAAGGTCAACTTCGTGGAG 3' } \\
\text { 5' GTGCTGAACTTGGGACTGGTA 3' }\end{array}$ & 21 & 60 & 350 \\
\hline $18 \mathrm{~S}$ & X01117 & $\begin{array}{l}\mathrm{F} \\
\mathrm{R}\end{array}$ & $\begin{array}{l}\text { 5'CGAAGACGATCAGATACCGTCGTAG3` } \\
\text { 5'AAGGGCATCACAGACCTGTTATTG3`' }\end{array}$ & 25 & 67 & 459 \\
\hline
\end{tabular}

$\mathrm{bp}$, base pair; $\mathrm{F}$ and $\mathrm{R}$, forward and reverse primer. 
The protein content of the membrane fraction of each solubilized samples was determined in triplicate using a Bio-Rad Protein Assay Kit with bovine serum albumin used as standard (Sigma). For Western blot analysis, equal amounts of proteins were resolved on a 10\% SDS-PAGE and transferred to PVDF membranes (Millipore). The PVDF membrane strips were incubated in blocking buffer with $5 \%$ non-fat milk (Sigma) in PBS for $2 \mathrm{~h}$ at room temperature, followed by overnight incubation at $4^{\circ} \mathrm{C}$ with one of the polyclonal anti-Kv4.2, anti-Kv4.3, anti-Kv1.4 antibodies at the concentration of $8 \mu \mathrm{g} / \mathrm{ml}$.

Three different polyclonal anti-Kv antibodies were used: i) the anti-Kv4.2 antibody generated against residues 454-469 of rat Kv4.2: (C)SNQLQSSEDEPAFVSK in the C-terminal part (Alomone); ii) the anti-Kv4.3 antibody generated against a sequence 451-468: (C)NEAL ELTGT PEEEH MGK in the C-terminus of rat Kv4.3 (Alomone); iii) the anti-Kv1.4 antibody against the sequence 589-655 of rat Kv1.4 with protein sequence PYLPS NLLKK FRSST SSSLG DKSEY LEMEE GVKES LCGKE EKCQG KGDDS ETDKN NCSNA KAVET DV and epitope localization in $C$ terminal part (Alomone).

After washing, membrane strips were incubated for $2 \mathrm{~h}$ at room temperature with secondary antibody (horseradish peroxidase-conjugated goat anti-rabbit, Sigma) diluted in blocking buffer and, after washes, bound antibodies were detected using chemiluminescence with the ECL plus Western Blotting Detection System (Amersham Life Sciences). Molecular weights were evaluated using prestained markers (11-170 kDa range, Fermentas). PVDF membranes were systematically stained with Red Ponceau so as to verify loading and transfert conditions and insure that loaded samples extracts were present in similar amouts.
The specificity of the antibody was tested by preadsorbing the antibody with the antigenic peptide which invariably lead to the absence of detectable signal. Single band arrows at $74 \mathrm{kDa}$ for anti-Kv4.2, $76 \mathrm{kDa}$ for anti-Kv4.3 and $72 \mathrm{kDa}$ anti-Kv1.4 are recognized. Densitometric analysis of the bands on the same film was done with an imaging densitometer (KDS 1D 2.0, Kodak Digital Science) and sofware. Results were expressed as densitometric units and presented as percentage of respective control mean value.

\section{Statistical analysis}

Data are given as mean \pm standard error of the mean (SEM) ( $n$ is number of experiments). One-way ANOVA was used to assess regional differences in the properties of myocytes isolated from CTR. Bonferroni test or Student's unpaired $t$-test was used to assess the statistical significance of differences between CTR and TGR27. A probability of $p<0.05$ was accepted as the level of significance.

\section{Results}

\section{Morphometric changes}

These changes were assessed both at the organ and the myocyte level. Fig. 1a shows representative macroscopic morphology of hearts coming from a CTR and a TGR27. Differences were visible to the naked eye: left ventricular and septal wall thicknesses were markedly increased in TGR27 compared to CTR, whereas the right ventricular wall thickness was unaffected. The wall thickness ratio of a)

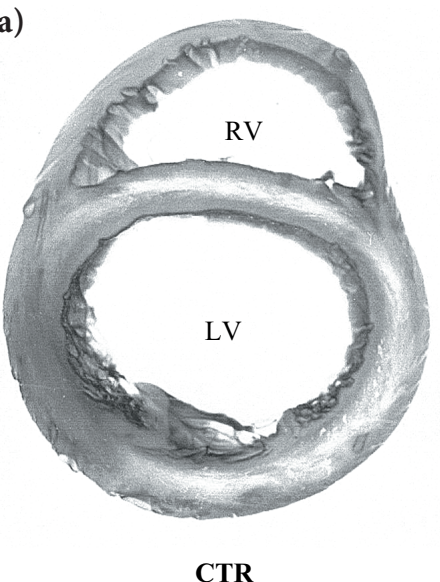

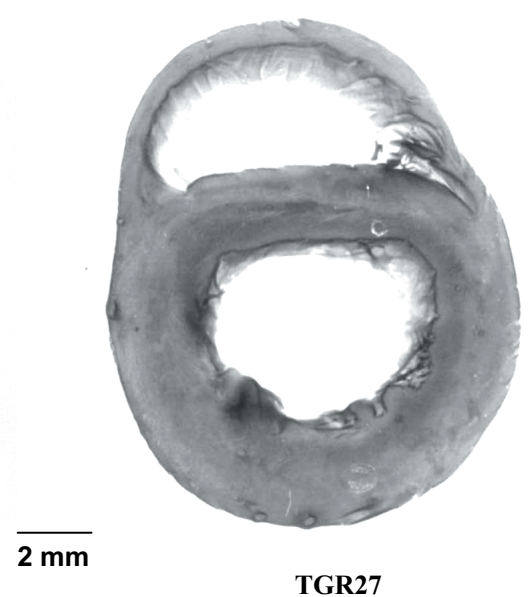

b)

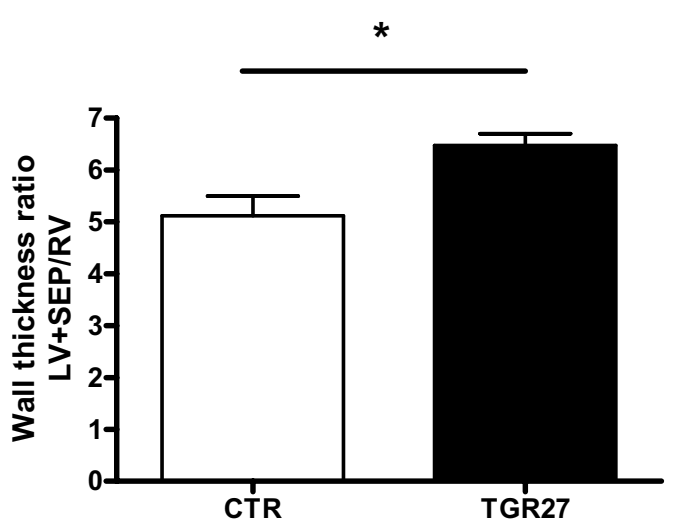

Figure 1. Evidence for a LV hypertrophy in TGR27 heart. a) Transversal slices of a CTR and a TGR27 heart. b) Ventricular wall thickness ratio. Bar values are means \pm SE derived from 8 to 13 measurements obtained on 3 rats in each group. RV, right ventricle; $L V$, left ventricle; SEP, septum; ${ }^{*} p<0.05$ compared with CTR. 


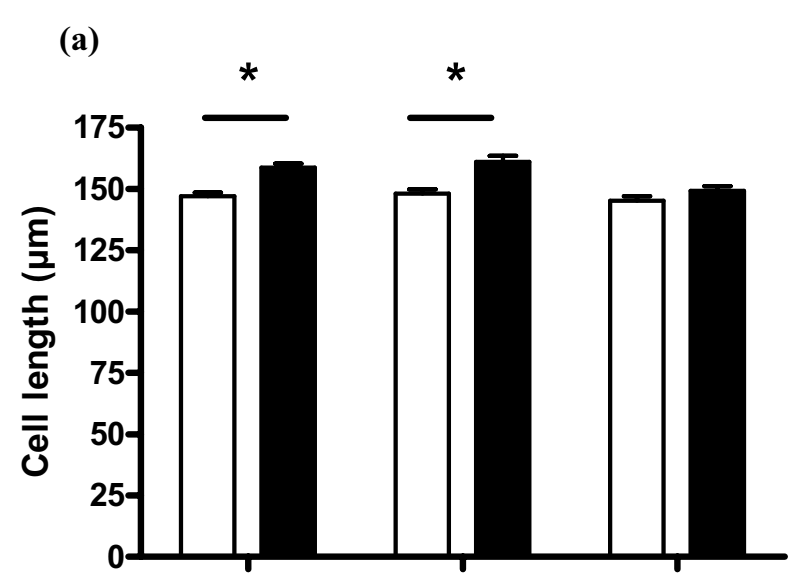

(b)
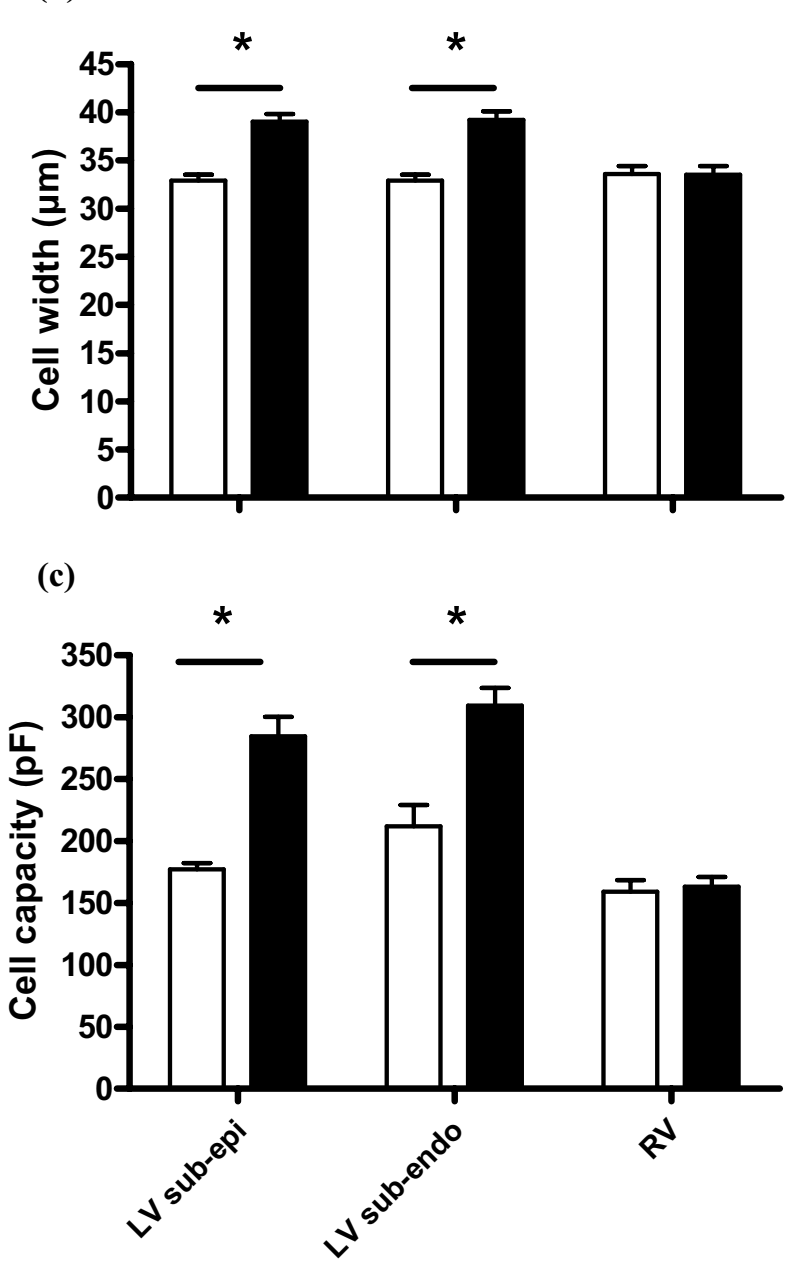

Figure 2. Cell characteristics of CTR and TGR27 heart. a) Cell length. b) Cell width. c) Cell capacity. Bar values are means \pm SE, $n=90$ cells isolated from three rats in (a) and (b) for each group and each region, $n=35$ to 44 cells in (c) isolated on 8 to 10 rats in each group. ${ }^{\star} p<0.05$ compared with CTR. LV sub-epi, LV subepicardial ventricular tissues; LV sub-endo, LV sub-endocardial ventricular tissues. left ventricle to right ventricle was found significantly increased in TGR27 compared to CTR (6.47 $\pm 0.23, n=13$ vs. $5.12 \pm 0.38, n=8$ in 3 TGR27 and 3 CTR, respectively) (Fig. 1b). These results are in agreement with the development of a ventricular hypertrophy in the left but not in the right part of TGR27 heart. In CTR, myocyte dimensions (Fig. 2a,b) were very similar in the three regions studied while length and width were both significantly increased in left ventricular myocytes from TGR27 by about 8 and 20\%, respectively. Such a modification was not observed in right ventricular myocytes. Fig. $2 c$ shows the mean capacity of myocytes from the three regions in CTR and TGR27. In CTR, it was significantly larger in myocytes from the endocardium than from the epicardium or the right ventricular wall. In TGR27, myocyte capacity was increased by about 60 and $46 \%$ in epicardium and endocardium, respectively, compared to CTR. Such an increase was not observed in right ventricular myocytes. Taken together, these results show that TGR27 exhibit a hypertrophy of the left ventricular myocytes but not of the right ventricular myocytes.

\section{AP measurement}

Typical AP recordings from the three different ventricular regions under study in CTR and TGR27 are illustrated in Fig. 3a-c. No differences were observed in AP amplitude and diastolic membrane potential. In CTR, AP duration was longer in myocytes isolated from the sub-endocardium than in myocytes from the sub-epicardium or from the right ventricular free wall. For each region, AP duration was statistically increased in TGR27 compared to CTR (Fig. 3d-f). In order to elucidate the nature of the currents responsible for the increase in AP duration, we study the most important currents which contribute to the repolarization in rat ventricular cells.

\section{Potassium currents}

Three major potassium currents were evaluated in the three selected ventricular regions, the transient outward current, $\mathrm{I}_{\mathrm{to}}$, the delayed rectifier current, $\mathrm{I}_{\mathrm{K}}$ and the inward rectifier $\mathrm{I}_{\mathrm{K} 1}$. The insets in Fig. $4 \mathrm{a}-\mathrm{c}$ show representative families of $\mathrm{I}_{\mathrm{to}}$ current records taken from individual left and right ventricular myocytes from CTR and TGR27. In CTR there was a regional distribution of $\mathrm{I}_{\text {to }}$ density with the right ventricular myocytes having the largest value (at $+60 \mathrm{mV}): 22.8 \pm 2.1 \mathrm{pA} / \mathrm{pF}$ compared to $14.9 \pm 0.8 \mathrm{pA} / \mathrm{pF}$ in epicardium and $10.9 \pm 1.1 \mathrm{pA} / \mathrm{pF}$ in endocardium. Such a regional difference was not observed for $\mathrm{I}_{\mathrm{K}}$ (Fig. 4d-f) and for $\mathrm{I}_{\mathrm{K} 1}$ (results not shown). In TGR27 $\mathrm{I}_{\text {to }}$ density was reduced as compared to CTR by about $30 \%$ in epicardium and endocardium and by $40 \%$ in the right ventricle. In TGR27 the highest $\mathrm{I}_{\text {to }}$ density was observed in the right ventricle (at $+60 \mathrm{mV}): 13.7 \pm 1.3 \mathrm{pA} / \mathrm{pF}$ compared to $10.6 \pm 0.8 \mathrm{pA} / \mathrm{pF}$ in epicardium and $7.4 \pm 1.1 \mathrm{pA} / \mathrm{pF}$ in 


\section{LV sub-epi}

(a)

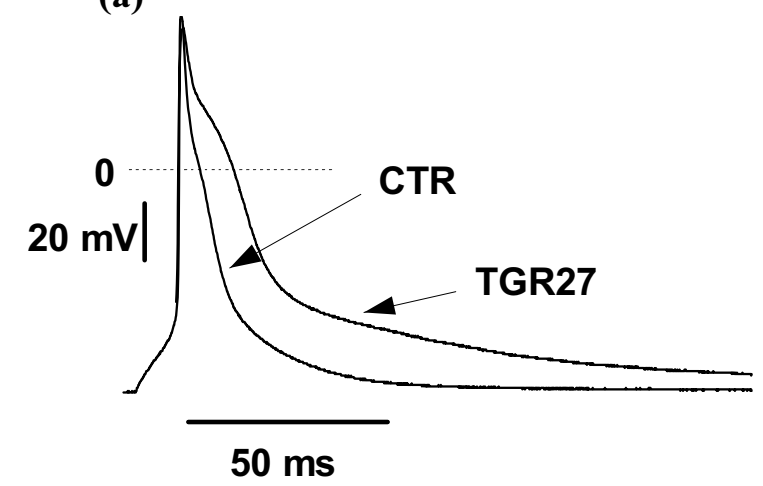

(d)

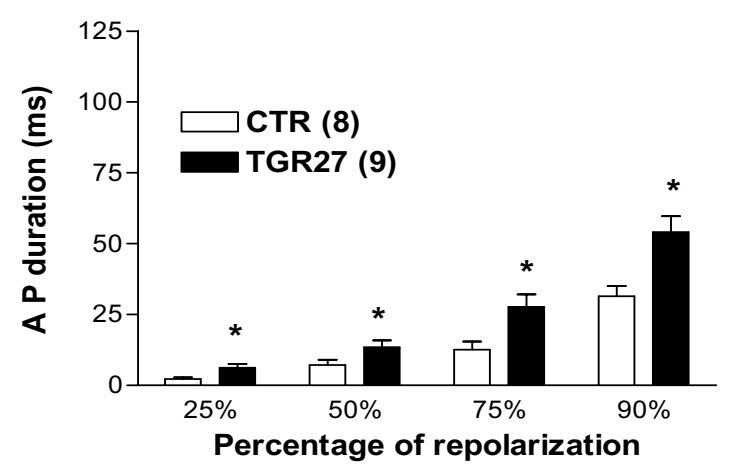

\section{LV sub-endo}

(b)

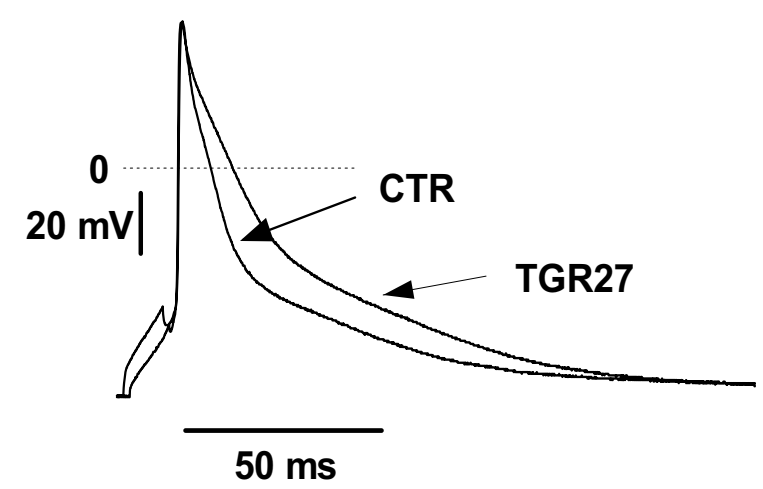

(e)

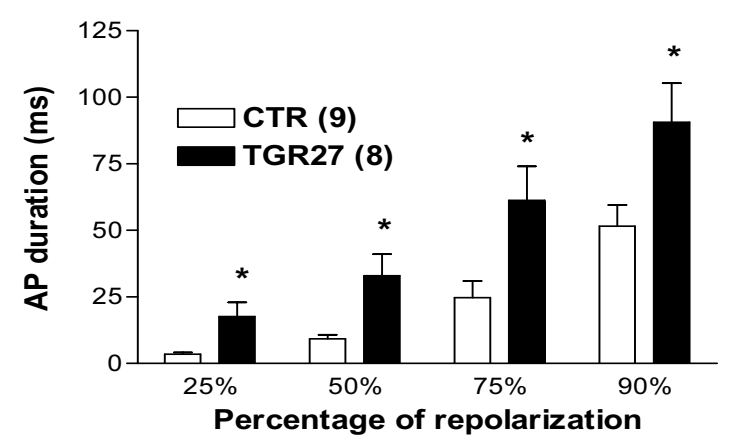

RV

(c)

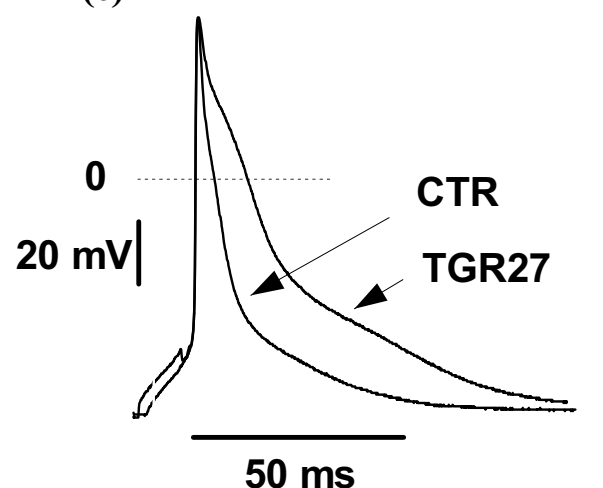

(f)

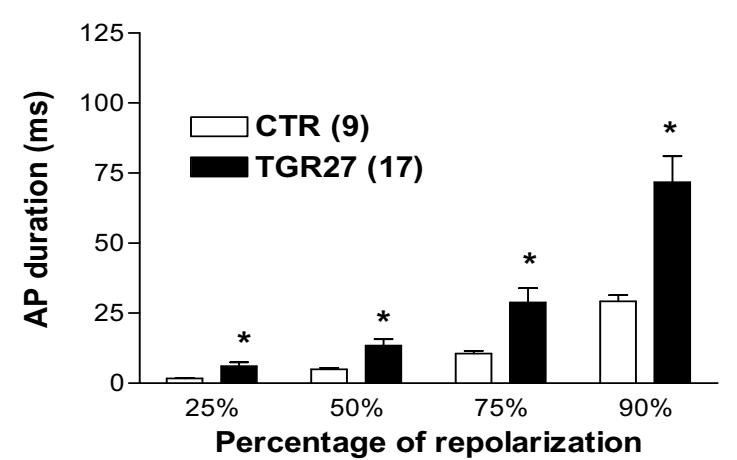

Figure 3. Representative action potentials $(\mathrm{AP})(\mathrm{a}-\mathrm{c})$ and mean values of AP duration $(\mathrm{d}-\mathrm{f})$ recorded in myocytes from CTR and TGR27 heart. Bar values are means \pm SE derived from $n$ (values in brackets) myocytes obtained on 3 to 4 rats in each group. ${ }^{*} p<0.05$ compared with CTR. 
LV sub-epi

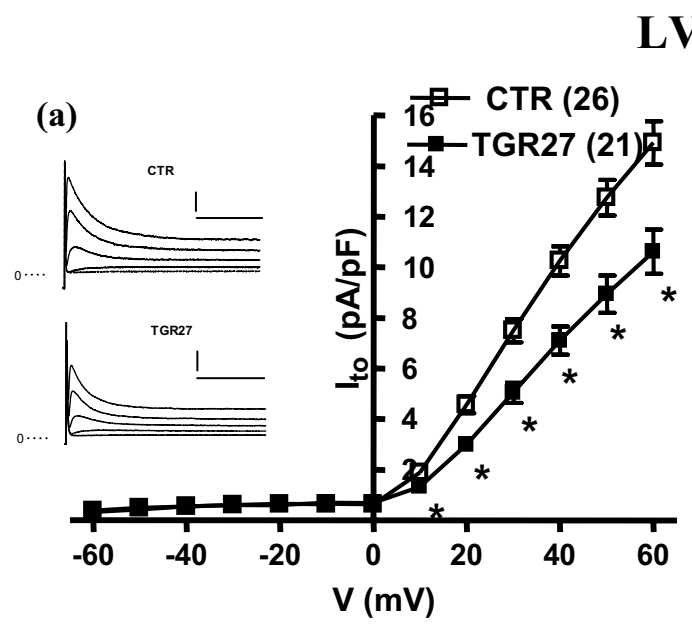

(a) (d)

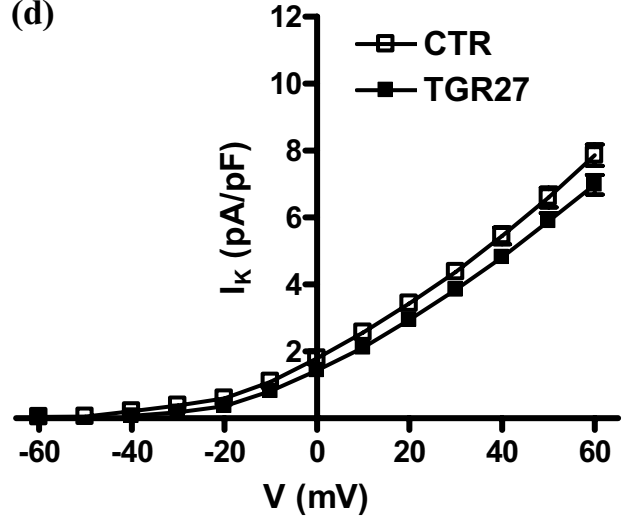

\section{LV sub-endo}

(b)

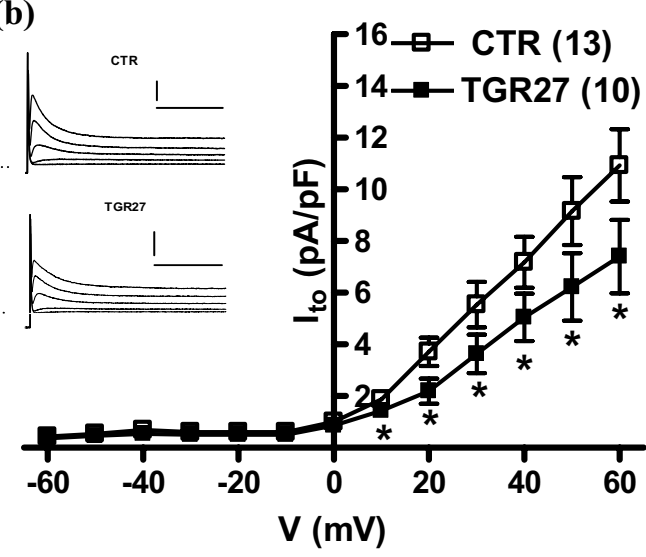

(e)

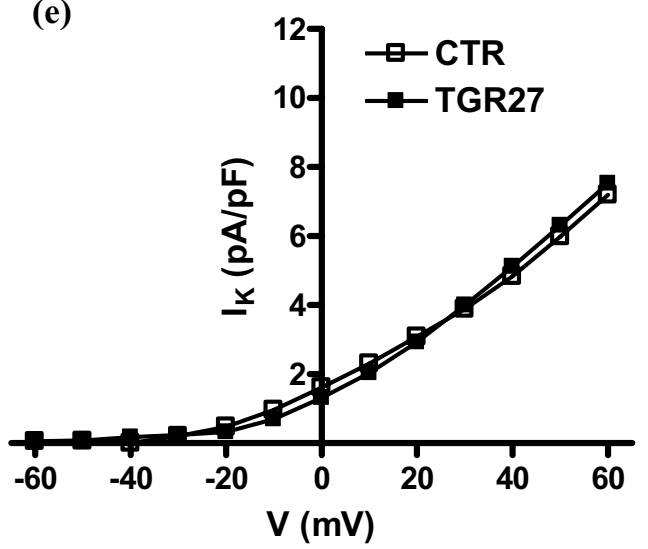

RV

(c)

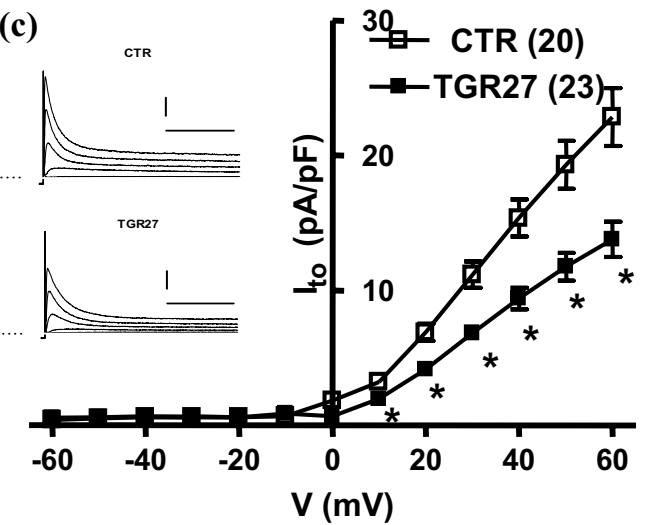

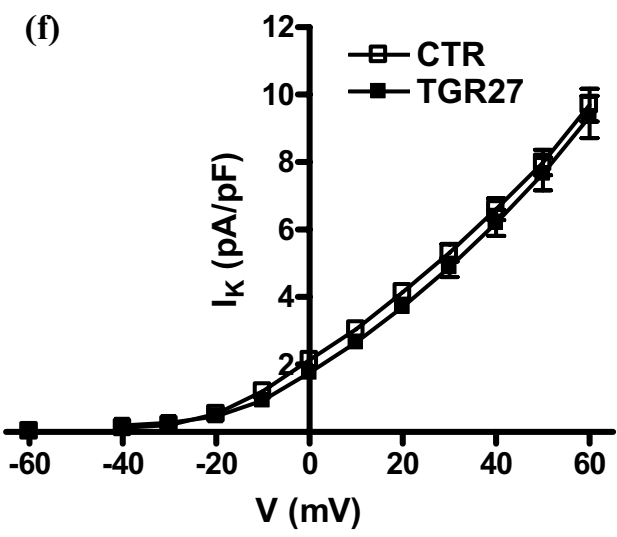

Figure 4. Potassium currents in LV sub-epi (a, d), LV sub-endo (b, e) and RV (c, f) myocytes in CTR and TGR27. a), b), c) Mean Ito density-voltage $(V)$ relationship curves. d), e), f) Mean delayed rectifier potassium current $\left(I_{K}\right)$ density-voltage relationship curves. Bar values are means \pm SE derived from $n$ (values in brackets) myocytes obtained on 8 to 10 rats in each group. The insets show representative potassium current traces recorded during depolarizing steps delivered at $0.1 \mathrm{~Hz}$ and varying between -20 and $+60 \mathrm{mV}$ by $20 \mathrm{mV}$ steps from a holding potential of $-80 \mathrm{mV}$. The transient outward current was measured as the difference between the peak outward current and the current at the end of 600-ms depolarizing pulses while sustained current was measured at the end of 600-ms depolarizing pulses with respect to the zero of the A/D converter. Horizontal bars $200 \mathrm{~ms}$, vertical bars $5 \mathrm{pA} / \mathrm{pF}$; ${ }^{\star} p<0.05$ compared with CTR. 


\section{LV sub-epi}

(a)

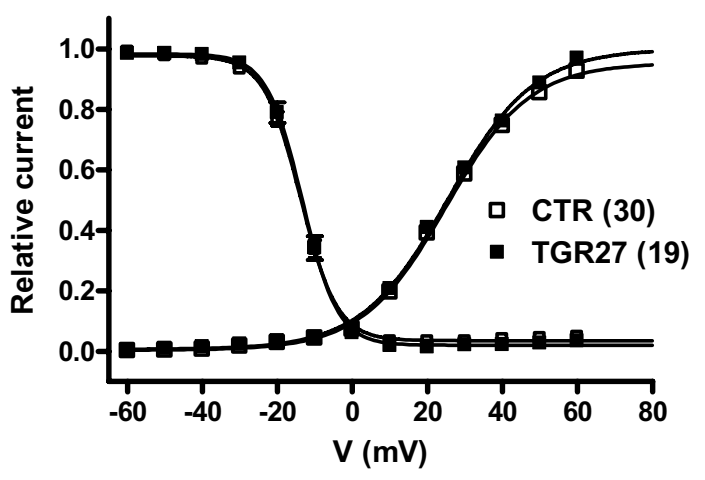

(d)

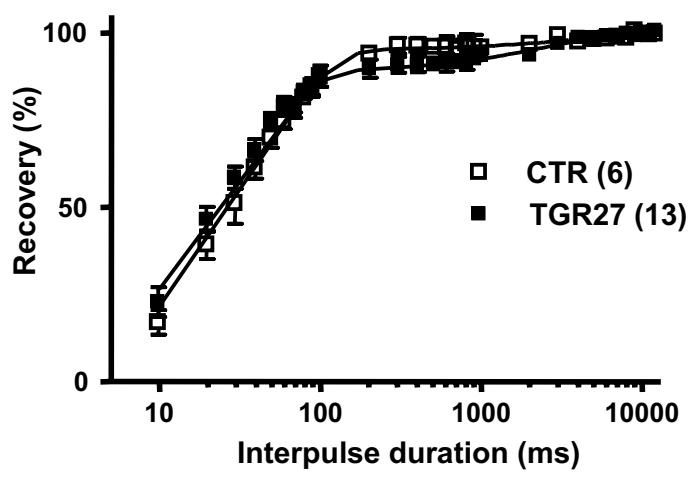

\section{LV sub-endo}

(b)

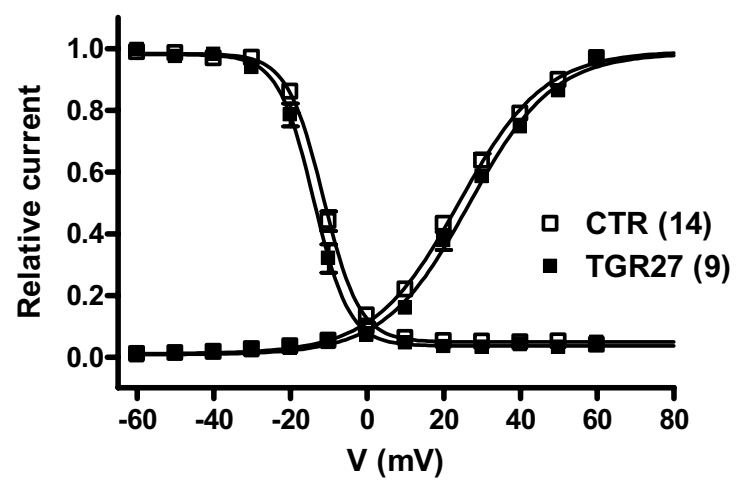

(c)

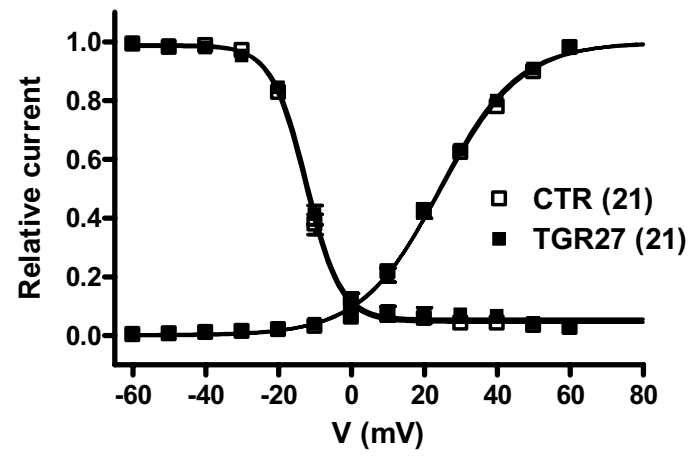

(e)

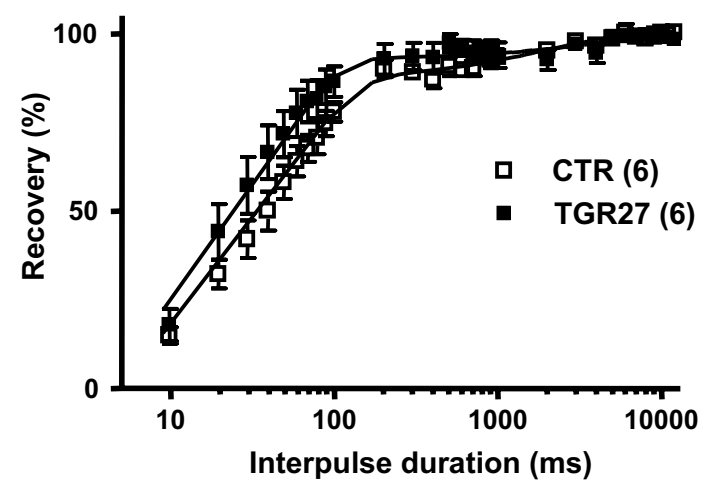

RV

(f)

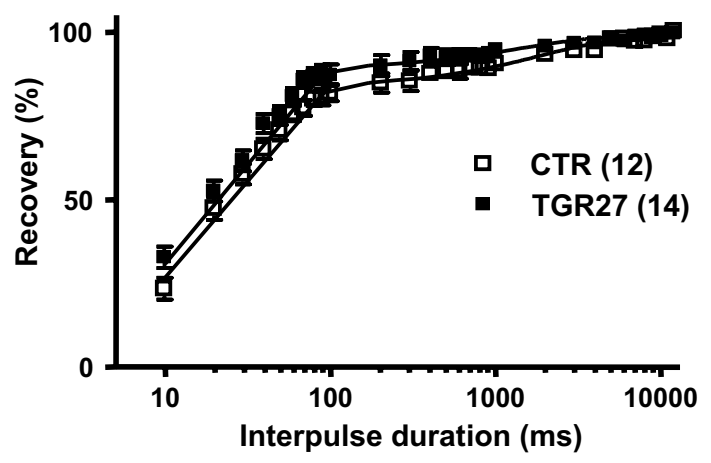

Figure 5. Kinetics of the transient outward current in LV sub-epi (a, d) LV sub-endo (b, e) and RV (c, f) myocytes in CTR and TGR27. a), b), c) Voltage-dependent activation and inactivation. The relations are fitted by a Boltzmann equation. Half-activation (in $\mathrm{mV}$ ) occurred at $25.3 \pm 0.7$ (a), $24.2 \pm 1.0$ (b), $24.0 \pm 0.7$ (c) in CTR and $24.9 \pm 0.9$ (a), $26.4 \pm 0.9$ (b), $23.8 \pm 1.0$ (c) in TGR. Half-inactivation (in $\mathrm{mV}$ ) occurred at $-13.8 \pm 0.7$ (a), $-12.3 \pm 0.7$ (b), $-13.4 \pm 0.7$ (c) in CTR and $-13.4 \pm 0.8$ (a), $-14.1 \pm 1.0$ (b), $-12.9 \pm 0.5$ (c) in TGR. d), e), f) Recovery from inactivation elicited by $600 \mathrm{~ms},+50 \mathrm{mV}$ depolarizing pulses applied at various intervals after the conditioning pulse. The relations are fitted by a double exponential with the following fast (in ms) and slow time constants (in s), respectively: $38.8 \pm$ 5.4, $3.4 \pm 0.4$ (d), $48.5 \pm 5.5,2.3 \pm 0.1$ (e), $24.8 \pm 2.7,2.9 \pm 0.4$ (f) in CTR and 28.8 $\pm 2.8,3.0 \pm 0.3$ (d), $36.1 \pm 6.7,3.1 \pm 0.1$ (e), $20.7 \pm 1.6$, $2.1 \pm 0.5$ (f) in TGR27. Bar values are means \pm SE derived from $n$ (values in brackets) myocytes obtained on 6 to 8 rats in each group. 

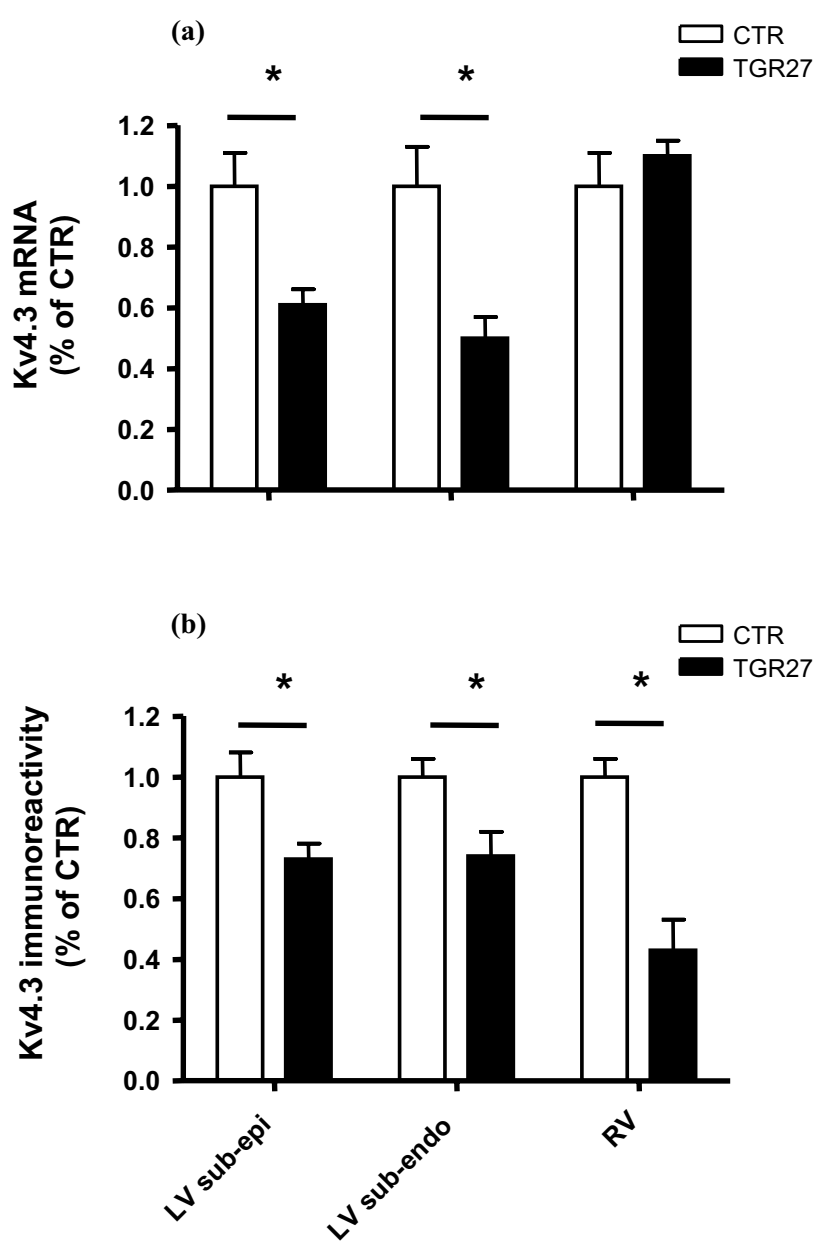

(c)

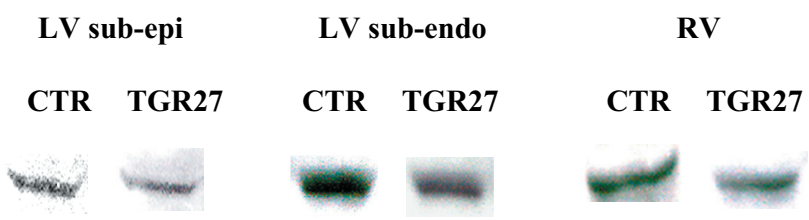

Figure 6. K channel expression in LV sub-epi, LV sub-endo and RV tissues of TGR27. a) mRNA levels of Kv4.3 channels ( 5 rats in each group). b) Protein expression of Kv4.3 channels ( 3 to 4 rats in each group).c) Western blot of Kv4.3 channel-subunit immunoreactive proteins. Data are expressed as percentage of CTR mean value. Bar values are means \pm SE. ${ }^{*} p<0.05$ compared with CTR.

endocardium, similarly to the distribution in CTR. Due to the fact that altered channel kinetics may contribute to a smaller current amplitude of $\mathrm{I}_{\mathrm{to}}$, we analyzed its kinetic properties. The inactivation time constants (at $+60 \mathrm{mV}$ ) were in the range of 40-60 ms for the three regions studied in CTR and tended to be longer, though not significantly, in myocytes isolated from TGR27. The activation, inactivation and reactivation curves of
$\mathrm{I}_{\text {to }}$ were also established. No significant changes were observed between CTR and TGR27 whatever the region (Fig. 5).

Potassium channel subunit protein expression

Fig. 6a shows a significant decrease in mRNA content between CTR and TGR27 left ventricle for Kv4.3 channel subunit expression, whereas such a change was not observed between CTR and TGR27 right ventricle. Neither the Kv4.2 and Kv1.4 mRNA levels nor the Kv2.1 mRNA levels (results not shown) were changed between CTR and TGR27 for the three regions studied.

Western blot analysis was performed to evaluate the $\mathrm{K}$ channel protein levels. The expression of Kv4.3 protein was found decreased both in left (sub-epicardial and sub-endocardial) and right ventricles isolated from TGR27 compared to CTR (Fig. 6b,c) while the expression of Kv4.2 and Kv1.4 proteins were unchanged between CTR and TGR27 for the two groups (results not shown).

\section{L-type calcium current and the sodium-calcium exchange current}

Fig. 7a-c shows the $\mathrm{I}_{\mathrm{Ca}, \mathrm{L}}$ density-voltage relationships established from the three ventricular regions of CTR and TGR27. Representative families of $\mathrm{I}_{\mathrm{Ca}, \mathrm{L}}$ current records are shown for each region in inset. At $+10 \mathrm{mV}, \mathrm{I}_{\mathrm{Ca}, \mathrm{L}}$ currents had similar amplitude in myocytes isolated from the three regions of CTR. They were also of equal magnitude in myocytes isolated from the left ventricular epicardium and endocardium of TGR27 while a non significant increase was noted in the right ventricular myocytes. Concerning the $\mathrm{I}_{\mathrm{NCX}}$ density, no significant difference was observed between regions in CTR or between the two groups of rats for each region (Fig. 7d-f). It is worth noting that in measurements concerning $\mathrm{I}_{\mathrm{NCX}}$ in endocardial myocytes the sample sizes were relatively small, leading to the possibility of Type II error. Fig. 8 shows the activation, inactivation and reactivation curves of $\mathrm{I}_{\mathrm{Ca}, \mathrm{L}}$. No significant changes were recorded between CTR and TGR27 whatever the region.

\section{Discussion}

The present work is the first report of voltage-clamp experiments carried in ventricular myocytes isolated from the TGR27 model, a well-established monogenic model of severe arterial systemic hypertension (Mullins et al. 1990). The main finding of this study is the presence of an electrical remodeling in the non-overloaded right ventricle in addition to the complete remodeling (i.e. association of structural and electrical remodeling) of the overloaded left ventricle. 


\section{LV sub-epi}

(a)

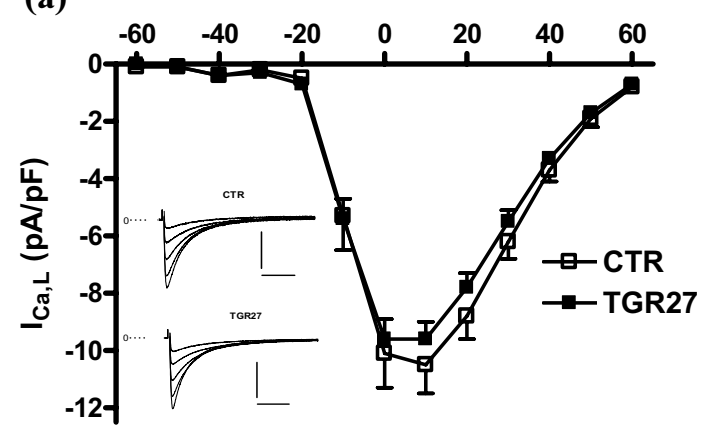

(d)

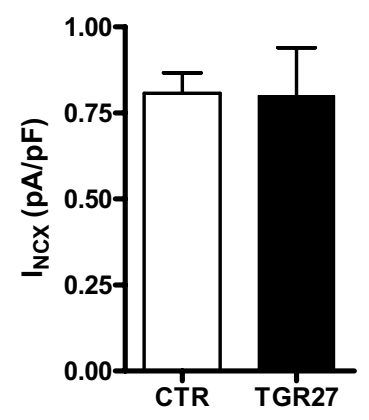

\section{LV sub-endo}

(b)

$\mathrm{V}(\mathrm{mV})$

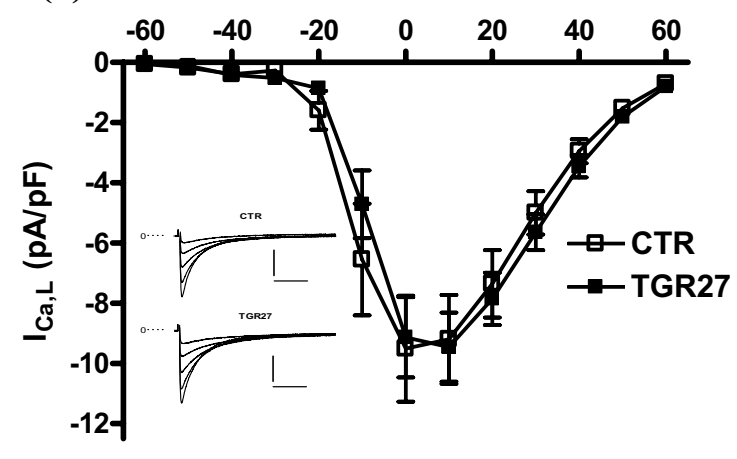

(e)

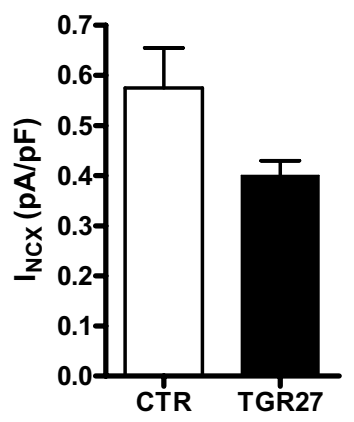

RV

(c)

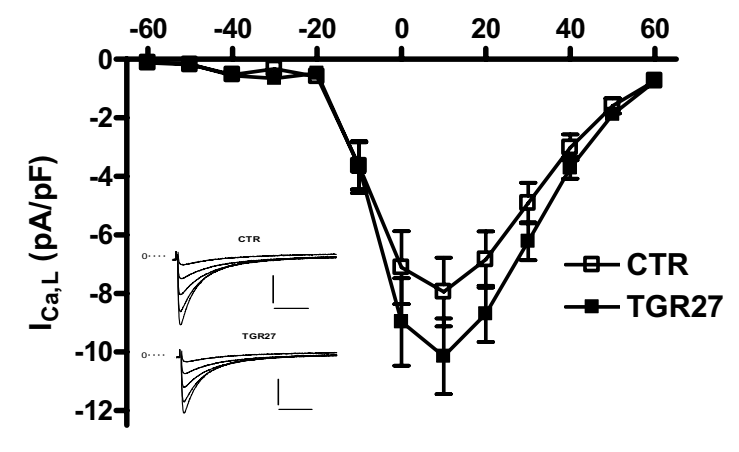

(f)

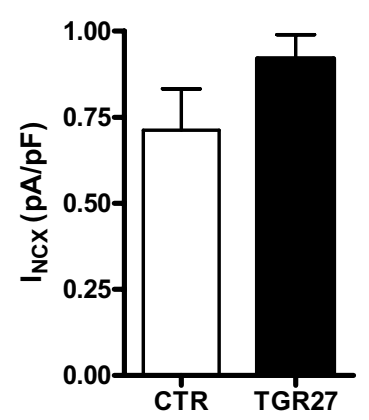

Figure 7. L-type calcium current and sodium-calcium exchange current in LV sub-epi (a, d), LV sub-endo (b, e) and RV (c, f) myocytes in CTR and TGR27. a), b), c) Mean $\mathrm{I}_{\mathrm{Ca}, \mathrm{L}}$ density-voltage (V) relationship curves. Bar values are means \pm SE derived from 9 to 14 myocytes obtained on 3 to 4 rats in each group. The insets show representative calcium current traces recorded during depolarizing steps delivered at $0.1 \mathrm{~Hz}$ and varying between +20 and $+60 \mathrm{mV}$ by $10 \mathrm{mV}$ steps from a holding potential of $-80 \mathrm{mV}$. The current was measured as the difference between the peak inward current and the current at the end of 245-ms depolarizing pulses. The smaller current component between -50 and $-30 \mathrm{mV}$ corresponds to the $\mathrm{I}_{\mathrm{Ca} \text { (TTX) }}$ component (for details, see Aggarwal et al. 1997). Horizontal bars, $50 \mathrm{~ms}$, vertical bars, $5 \mathrm{pA} / \mathrm{pF}$. d), e), f) Histogram showing mean density of $\mathrm{I}_{\mathrm{NCX}}$ recorded at $-80 \mathrm{mV}$. Bar values are means $\pm \mathrm{SE}$ derived from 10 to 12 myocytes obtained on 3 to 4 rats in each group. 


\section{LV sub-epi}

(a)

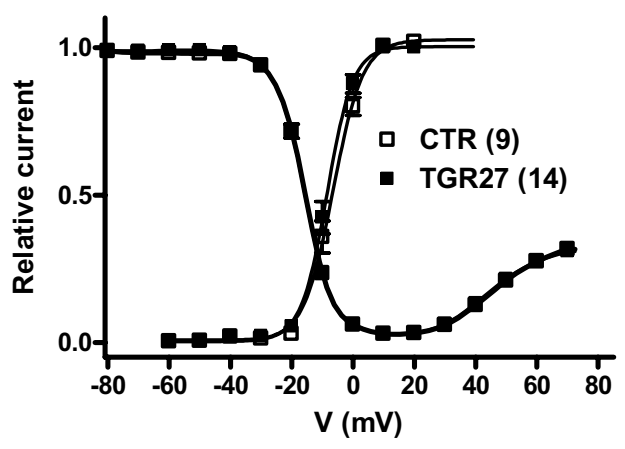

(d)

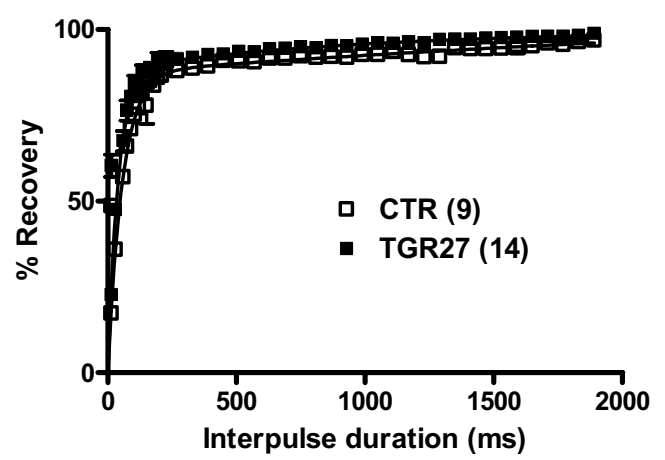

\section{LV sub-endo}

(b)

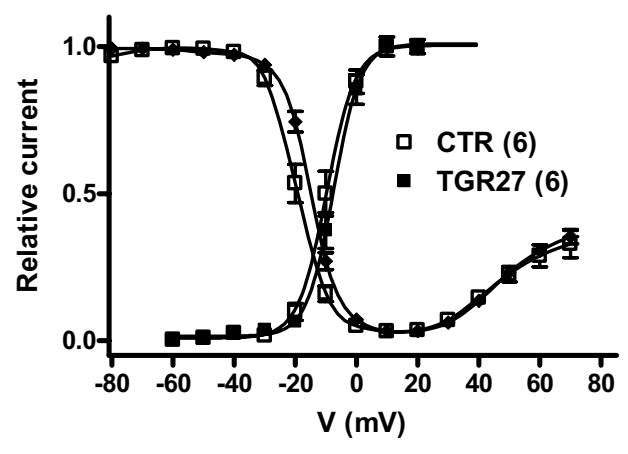

(c)

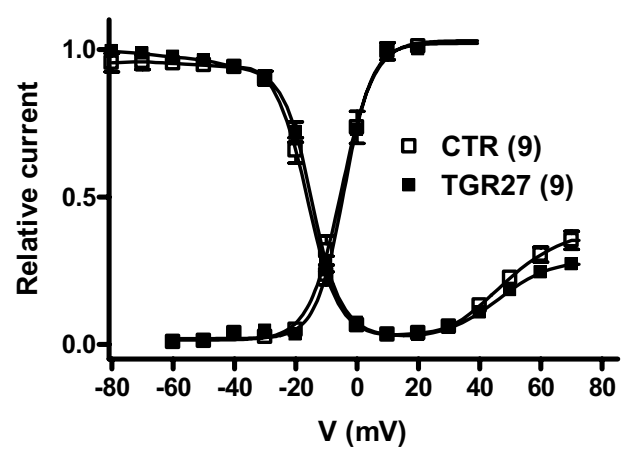

(e)

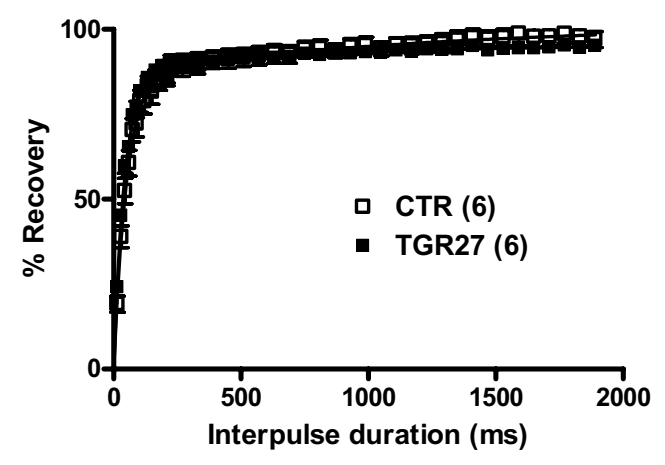

RV

(f)

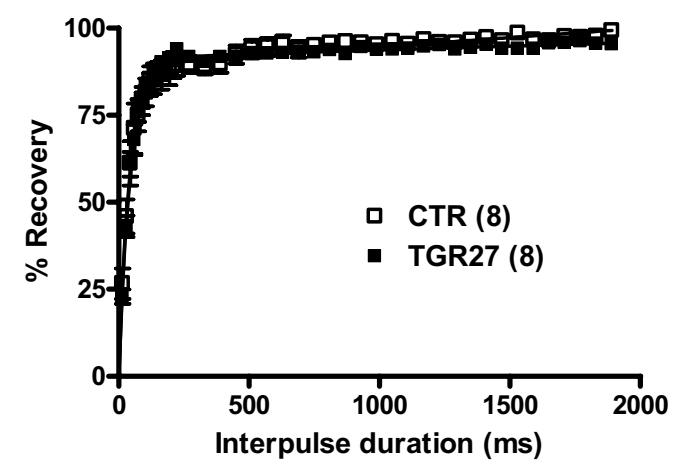

Figure 8. Kinetics of the L-type calcium current in LV sub-epi (a, d), LV sub-endo (b, e) and RV (c, f) myocytes in CTR and TGR27. a), b), c) Voltage-dependent activation and inactivation. The activation curves are fitted by a Boltzmann equation. Half-activation (in $\mathrm{mV}$ ) occurred at $-6.4 \pm 1.0$ (a), $-9.6 \pm 1.4$ (b), $-4.6 \pm 1.4$ (c) in CTR and $-7.0 \pm 1.2$ (a), $-6.6 \pm 1.1$ (b), $-4.0 \pm 1.1$ (c) in TGR27. The inactivation curves do not follow a sigmoidal function and are not fitted by a Boltzmann equation. The half-inactivation (in $\mathrm{mV}$ ), determined by interpolation, occurred at $-15.5 \pm 0.4$ (a), $-17.6 \pm 1.3$ (b), $-16.4 \pm 1.0$ (c) in CTR and $-15.6 \pm 0.4$ (a), $-15.8 \pm 1.0$ (b), $-15.3 \pm 0.8$ (c) in TGR27. d), e), f) Recovery from inactivation elicited by $250 \mathrm{~ms},+10 \mathrm{mV}$ depolarizing pulses applied at various intervals after the conditioning pulse. The relations are fitted by a double exponential with the following fast (in ms) and slow time constants (in s), respectively: $42.7 \pm 1.1,1.0 \pm 0.2$ (d), $46.6 \pm$ 4.2, $0.7 \pm 0.3$ (e), $44.6 \pm 4.5,0.8 \pm 0.1$ (f) in CTR and $40.4 \pm 1.6,1.2 \pm 0.2$ (d), $39.3 \pm 2.3,1.1 \pm 0.2$ (e), $43.0 \pm 3.6,1.2 \pm 0.1$ (f) in TGR27. Bar values are means \pm SE derived from $n$ (values in brackets) myocytes obtained on 3 to 4 rats in each group. 
Ventricular morphometric changes and cardiomyocyte size

In the TGR27 model, our measurements confirm the existence of left ventricular hypertrophy (Engler et al. 1998; Kurdi et al. 2005) and extend this data at the cellular level. Indeed, both the length and width of cardiomyocytes are increased as well as myocyte membrane capacitance. This indicates that the enlargement in wall thickness results, at least in part, from myocyte hypertrophy. Concerning the right ventricle, no sign of hypertrophy was detected at either the organ or myocyte level. The right ventricular myocyte-capacitance measurement was corroborated by morphometric determination of right ventricular myocyte dimensions which showed no significant difference between TGR27 and CTR groups concerning length and width of myocytes. This is in disagreement with the results of Rothermund et al. (2002) who find in 10-week-old TGR27 an increase in cardiomyocyte width of the right ventricle, indicating the development of right ventricular hypertrophy. This discrepancy might be due to the method (hematoxylin-eosin stain-processed tissue sections) used by the authors which can introduce some distortion in measurement of cardiomyocyte dimensions (Gerdes 2002).

\section{AP duration}

Prolonged AP duration is a typical feature of hypertrophied myocardium whatever the type of chronic pressure overloading used (Hart 1994). Our study shows a significant increase in AP duration both in left ventricular myocytes isolated from the sub-epicardium or from the sub-endorcardium of TGR27 compared to CTR. In SHR, it has been shown that AP duration was significantly increased only in epicardial myocytes (McCrossan et al. 2004). This difference of results in endocardial myocytes is probably related to a difference of model (TGR27 vs. SHR) rather than a difference of recording technique (conventional whole-cell recording vs. perforated patch recording) since we have previously shown that similar AP time courses could be obtained with the two techniques (Chouabe et al. 1997). Moreover our results show a significant increase in AP duration in right ventricular myocytes from TGR27 compared to CTR. This result is interesting but not surprising because other factors than hypertrophy can contribute to the lengthening of AP (Tomaselli and Marban 1999).

\section{Ionic basis of AP prolongation}

In rat hearts, the ventricular APs recorded at room temperature in either cardiac tissue (Momtaz et al. 1996) or isolated cardiomyocytes (Josephson et al. 1984a; Chouabe et al. 1997) display two distinct plateau phases: an early "high" plateau at positive potentials followed by the onset and slow decay of a "low" plateau which occurs at potentials negative to $-40 \mathrm{mV}$. The time-course of the repolarization phase of cardiac AP is controlled by a fine balance between inward and outward currents. In rat heart, the inward currents are mainly $\mathrm{I}_{\mathrm{Ca}, \mathrm{L}}$ for the high plateau and the current generated by the Na-Ca exchange mechanism for the low plateau (Mitchell et al. 1984; Espinosa et al. 2000). The transient outward current is chiefly responsible for the high plateau while $\mathrm{I}_{\mathrm{K}}$ and $\mathrm{I}_{\mathrm{K} 1}$ are responsible for the low plateau (Josephson et al. 1984b; Josephson 1988; Apkon and Nerbonne 1991). $I_{C a, L}$ densities, $I_{C a, L}$ kinetic parameters and $I_{N C X}$ densities were not different between CTR and TGR27 in the three regions studied. These results are similar to those reported from left ventricular myocytes of SHR (Cerbai et al. 1994; Chen-Izu et al. 2007) and suggest that these inward currents do not play a major role in prolongation of AP duration in ventricular myocytes of TGR27. Among the outward currents, only $\mathrm{I}_{\text {to }}$ was found modified in the three regions under study in TGR27. The density was decreased but no significant change of kinetic parameters was noted. The decrease in $\mathrm{I}_{\text {to }}$ density observed in TGR27 endocardial myocytes is in contrast with the absence of modification in SHR (Goltz et al. 2007). Moreover, $I_{\text {to }}$ kinetic parameters are not modified in endocardial and epicardial ventricular myocytes of TGR27 in contrast with the decrease observed (significant only in epicardial myocytes) in SHR (Goltz et al. 2007). Taken together, the results argue for a possible different etiology of the cardiac remodeling in these two rat models (Goltz et al. 2007).

\section{Molecular basis of decreased density of $I_{t o}$}

The molecular correlate of $\mathrm{I}_{\text {to }}$ seems reasonably well established in rat ventricular myocytes. Among the Kv genes expressed in the rat ventricles, Kv1.4, Kv4.2 and Kv4.3 seem to be the likely candidates for this current (Nerbonne 2000). Because mRNA levels of $K$ channels are not always predictive of protein levels, we also performed experiments to determine the expression levels for the corresponding proteins (Xu et al. 1996).

Neither the mRNA levels nor the protein levels of Kv4.2 and Kv1.4 were significantly modified both in left and right ventricles of TGR compared to CTR (results not shown). The unaffected Kv4.2 mRNA levels in TGR27 is in contrast to the decrease reported in SHR left ventricle (Goltz et al. 2007). Depending of the cardiac hypertrophy model used, the Kv1.4 mRNA levels were found either not modified or decreased. Our results confirm and extend the hypothesis that regulation of the Kv genes may be related to the etiology of the hypertrophy ((Capuano et al. 2002) and references therein).

Moreover, our results show that Kv4.3 protein levels were significantly decreased both in left (epicardial and 


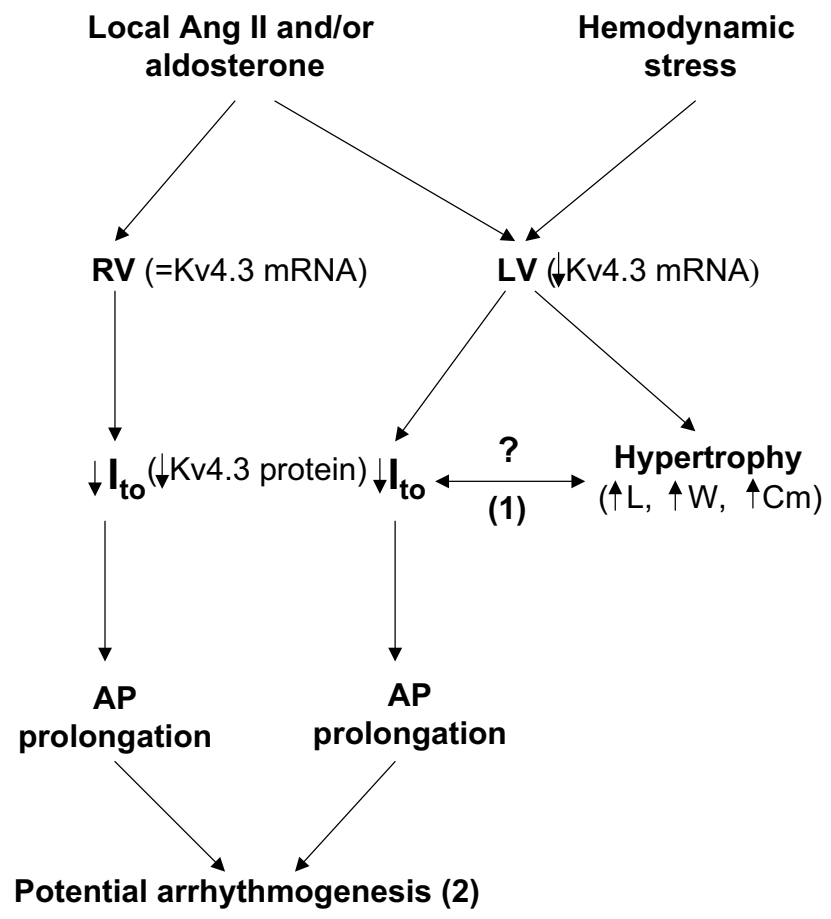

Figure 9. Summary of ventricular myocyte remodelling in TGR27 model and possible consequences. (1), Sanguinetti (2002); (2), Hill (2003).

endocardial) and right ventricular myocytes of TGR27 rats by 27 and $58 \%$, respectively, compared to CTR. Due to the fact that $\mathrm{Kv} 4.2$ and $\mathrm{Kv} 4.3$ form heteromultimeric channels to generate $\mathrm{I}_{\text {to }}$ in rat ventricular myocytes (at least for the fast component; (Oudit et al. 2001)), this decrease could provide the molecular basis of our electrophysiological observations of decreased density of $\mathrm{I}_{\text {to }}($ at $+60 \mathrm{mV})$ by about 29 , 32 and $40 \%$ in epicardial, endocardial and right ventricular myocytes of TGR27, respectively, compared to CTR. If, as expected, $\mathrm{Kv} 4.3$ protein decrease is associated with reduced mRNA expression in left ventricle of TGR27, Kv4.3 protein did decrease but without reduced mRNA expression in the right ventricle. This difference between the amounts of protein and of corresponding mRNA suggests that Kv4.3 could be differently regulated in left and right ventricular myocytes of our model (see below).

Possible causes of electrical remodeling in ventricular myocytes of TGR

Local angiotensin II (Ang II) production in the TGR27 heart has been proposed by Böhm et al. (1995) and shown by Zolk et al. (2002). Incubation of canine epicardial myocytes with Ang II for 2 to $52 \mathrm{~h}$ induced a decrease in $\mathrm{I}_{\text {to }}$ density with no modification in mRNA levels for either
Kv4.3 or Kv1.4. This posttranslational effect of Ang II was attributed to a change in the voltage dependence of activation and inactivation of $\mathrm{I}_{\mathrm{to}}$ (Yu et al. 2000). In order to study the mechanism of $\mathrm{I}_{\text {to }}$ regulation by Ang II, Doronin et al. (2004) co-expressed Kv4.3 with the Ang II type 1 (AT1) receptor in HEK 293 cells. They concluded that the dominant mechanism of $\mathrm{I}_{\mathrm{to}}$ inhibition by Ang II was due to the association of the AT1 receptors with $\mathrm{Kv} 4.3$ which thereby regulates the cell surface representation of $\mathrm{I}_{\text {to }}$ channel. Moreover, it has been shown that activation of AT1 receptors or mechanical stretch decreased Kv4.3 mRNA by activating NADPH oxidase on cultured neonatal rat ventricular myocytes (Zhou et al. 2008). In left ventricular myocytes of TGR27, we can suppose that the AT1 receptor-stretch downregulation of $\mathrm{Kv} 4.3$ expression could perhaps be activated in response to the arterial systemic hypertension.

It has been shown that the basal plasma aldosterone level was increased in TGR27 $(\approx 78 \mathrm{pmol} / \mathrm{l})$ compared to CTR Sprague-Dawley rats $(\approx 23 \mathrm{pmol} / \mathrm{l}$ ) (see Fig. 2 in Rossi et al. 2000). In isolated rat adult cardiomyocytes, aldosterone (100 nmol/l, $48 \mathrm{~h}$ of exposure) induced a decrease in $\mathrm{I}_{\text {to }}$ density and a downregulation of Kv4.2 mRNA secondarily to an increase in $\mathrm{I}_{\mathrm{Ca}, \mathrm{L}}$ which initiated $\mathrm{Ca}^{2+}$ signalling modulation. The $\mathrm{I}_{\text {to }}$ reduction was not associated with significant changes in its voltage- and time-dependent properties (Bénitah et al. 2001; Perrier et al. 2004). Once again, our results do not fit completely with these data since no modification in Kv4.2/3 mRNA levels was noted, even if an increase (although non significant) in $\mathrm{I}_{\mathrm{Ca}, \mathrm{L}}$ density was recorded in the right ventricular myocytes in TGR27 vs. CTR. Nevertheless, despite the methodological and model differences, it is plausible that Ang II and/or aldosterone play an important role in the electrical remodeling of TGR ventricular myocytes even if other factors are undoubtedly involved. Fig. 9 summarizes the observed effects at the cellular level and extrapolates the likely consequences of the observed electrophysiological parameters on the whole heart functions.

In conclusion, the present work shows a differential remodeling between both ventricles of the TGR27 model, with only an electrical remodeling in the normotensive right ventricle, whereas left ventricle undergoes both structural and electrical remodeling. It suggests that the process of electrophysiological remodeling can be dissociated, at least in part, from the process of hypertrophy itself (Sanguinetti 2002; Furukawa and Kurokawa 2006).

Acknowledgements. We gratefully acknowledge the valuable collaboration of Jacqueline Amsellem for histological study. We wish to thank C. Berthier, G. Christé, D. Desplanches, M. Jospin for helpful comments and for correcting the English. Part of this work was supported by INSERM (PROGRES program). 


\section{References}

Aggarwal R., Shorofsky S. R., Goldman L., Balke C. W. (1997): Tetrodotoxin-blockable calcium currents in rat ventricular myocytes; a third type of cardiac cell sodium current. J. Physiol. (London) 505, 353-369

Apkon M., Nerbonne J. M. (1991): Characterization of two distinct depolarization-activated $\mathrm{K}^{+}$currents in isolated adult rat ventricular myocytes. J. Gen. Physiol. 97, 973-1011

Bachmann S., Peters J., Engler E., Ganten D., Mullins J. J. (1992): Transgenic rats carrying the mouse renin gene - morphological characterization of a low renin hypertension model. Kidney Int. 41, 24-36

Bénitah J.-P., Perrier E., Gomez A. M., Vassort G. (2001): Effects of aldosterone on transient outward $\mathrm{K}^{+}$current density in rat ventricular myocytes. J. Physiol. (London) 537, 151-160

Böhm M., Lee M., Kreutz R., Kim S., Schinke M., Djavidani B., Wagner J., Kaling M., Wienen W., Bader M., Ganten D. (1995): Angiotensin II receptor blockade in TGR(mREN2)27: effects of renin-angiotensin-system gene expression and cardiovascular functions. J. Hypertens. 13, 891-899

Capuano V., Ruchon Y., Antoine S., Sant M.-C., Renaud J.-F. (2002): Ventricular hypertrophy induced by mineralocorticoid treatment or aortic stenosis differentially regulates the expression of cardiac $\mathrm{K}^{+}$channels in the rat. Mol. Cell. Biochem. 237, 1-10

Cerbai E., Barbieri M., Mugelli A. (1994): Ionic basis of action potential prolongation of hypertrophied cardiac myocytes isolated from hypertensive rats of different ages. Cardiovasc. Res. 28, 1180-1187

Cerbai E., Crucitti A., Sartiani L., De Paoli P., Pino R., Rodriguez M. L., Gensini G., Mugelli A. (2000): Long-term treatment of spontaneously hypertensive rats with losartan and electrophysiological remodeling of cardiac myocytes. Cardiovasc. Res. 45, 388-396

Chen-Izu Y., Chen L., Banyasz T., McCulle S. L., Norton B., Scharf S. M., Agarwa A., Patwardhan A., Izu L. T., Balke C. W. (2007): Hypertension-induced remodeling of cardiac excitation-contraction coupling in ventricular myocytes occurs prior to hypertrophy development. Am. J. Physiol. 293, H3301-3310

Chouabe C., Espinosa L., Megas P., Chakir A., Rougier O., Freminet A., Bonvallet R. (1997): Reduction of $\mathrm{I}_{\mathrm{Ca}, \mathrm{L}}$ and $\mathrm{I}_{\text {tol }}$ density in hypertrophied right ventricular cells by simulated high altitude in adult rats. J. Mol. Cell. Cardiol. 29, 193-206

Chouabe C., Amsellem J., Espinosa L., Ribaux P., Blaineau S., Megas P., Bonvallet R. (2002): Reversibility of electrophysiological changes induced by chronic high-altitude hypoxia in adult rat heart. Am. J. Physiol. 282, H1452-1460

Doronin S. V., Potapova I. A., Lu Z., Cohen I. S. (2004): Angiotensin receptor type forms a complex with the transient outward potassium channel Kv4.3 and regulates its gating properties and intracellular localization. J. Biol. Chem. 279, 48231-48237

Engler S., Paul M., Pinto Y. M. (1998): The TGR(mRen2)27 transgenic rat model of hypertension. Regul. Pept. 77, 3-8
Espinosa L., Chouabe C., Morales A., Lachuer J., Fatemi M., Terrenoire C., Tourneur Y., Bonvallet R. (2000): Increased sodium-calcium exchange current in right ventricular cell hypertrophy induced by simulated high altitude in adult rats. J. Mol. Cell. Cardiol. 32, 639-653

Furukawa T., Kurokawa J. (2006). Potassium channel remodeling in cardiac hypertrophy. J. Mol. Cell. Card. 41, 753-761

Gerdes A. M. (2002): Cardiac myocyte remodeling in hypertrophy and progression to failure. J. Card. Fail. 8, S264-268

Goltz D., Schultz J.-H., Stucke C., Wagner M., Bassalay P., Schwoerer A. P., Ehmke H., Volk T. (2007): Diminished Kv4.2/3 but not KChIP2 levels reduce the cardiac transient outward current in spontaneously hypertensive rats. Cardiovasc. Res. 74, 85-95

Hart G. (1994): Cellular electrophysiology in cardiac hypertrophy and failure. Cardiovasc. Res. 28, 933-946

Hill J. A. (2003): Electrical remodeling in cardiac hypertrophy. Trends Cardiovasc. Med. 13, 316-322

Josephson I. R. (1988): Properties of inwardly rectifying $\mathrm{K}^{+}$channels in ventricular myocytes. Mol. Cell. Biochem. 80, 21-26

Josephson I. R., Sanchez-Chapula J., Brown A. M. (1984a): A comparison of calcium currents in rat and guinea pig single ventricular cells. Circ. Res. 54, 144-156

Josephson I. R., Sanchez-Chapula J., Brown A. M. (1984b): Early outward current in rat single ventricular cells. Circ. Res. $\mathbf{5 4 , 1 5 7 - 1 6 2}$

Kozhevnikov D. O., Yamamoto K., Robotis D., Restivo M., El-Sherif N. (2002): Electrophysiological mechanism of enhanced susceptibility of hypertrophied heart to acquired torsade. Circulation 105, 1128-1134

Kurdi M., Randon J., Cerrutti C., Bricca G. (2005): Increased expression of IL-6 and LIF in the hypertrophied left ventricle of TGR(mRen2)27 and SHR rats. Mol. Cell. Biochem. 269, 95-101

Lee M. A., Böhm M., Paul M., Bader M., Ganten U., Ganten D. (1996): Physiological characterisation of the hypertensive transgenic rat TGR(mREN2)27. Am. J. Physiol. 270, E919-929

McCrossan Z. A., Billeter R., White E. (2004): Transmural changes in size, contractile and electrical properties of SHR left ventricular myocytes during compensated hypertrophy. Cardiovasc. Res. 63, 283-292

Mitchell M. R., Powell T., Terrar D. A., Twist V. W. (1984): The effects of ryanodine, EGTA and low-sodium on action potentials in rat and guinea-pig ventricular myocytes: evidence for two inward currents during the plateau. $\mathrm{Br}$. J. Pharmac. 81, 543-550

Momtaz A., Coulombe A., Richer P., Mercadier J.-J., Coraboeuf E. (1996): Action potential and plateau ionic currents in moderately and severely DOCA-salt hypertrophied rat hearts. J. Mol. Cell. Cardiol. 28, 2511-2522

Mullins J. J., Peters J., Ganten D. (1990): Fulminant hypertension in transgenic rats harbouring the mouse Ren-2 gene. Nature 344, 541-544

Nerbonne J. (2000): Molecular basis of functional voltage-gated $\mathrm{K}^{+}$channel diversity in the mammalian myocardium. J. Physiol. (London) 525.2, 285-298

Oudit G. Y., Kassiri Z., Sah R., Ramirez R. J., Zobel C., Backx P. H. (2001): The molecular physiology of the cardiac transient 
outwerd potassium current $\left(\mathrm{I}_{\mathrm{to}}\right)$ in normal and deseased myocardium. J. Mol. Cell. Cardiol. 33, 851-872

Pachori A. S., Numan M. T., Ferrario C. M., Diz D. M., Raizada M. K., Katovich M. J. (2002): Blood pressure-independant attenuation of cardiac hypertrophy by AT(1)R-AS gene therapy. Hypertension 39, 969-975

Perrier E., Perrier R., Richard S., Bénitah J.-P. (2004): $\mathrm{Ca}^{2+}$ controls functional expression of the cardiac $\mathrm{K}^{+}$transient outward current via the calcineurin pathway. J. Biol. Chem. 279, 40634-40639

Rossi G. P., Sacchetto A., Rizzoni D., Bova S., Porteri E., Mazzocchi G., Belloni A. S., Bahcelioglu M., Nussdorfer G. G., Pessina A. C. (2000): Blockade of angiotensin II type 1 receptor and not of endothelin receptor prevents hypertension and cardiovascular disease in transgenic (mREN2)27 rats via adrenocortical steroid-independant mechanisms. Arterioscler. Thromb. Vasc. Biol. 20, 949-956

Rothermund L., Kreutz R., Kossmehl P., Fredersdorf S., Shakibaei M., Sculze-Tanzil G., Paul M., Grimm D. (2002): Early onset of chondroitin sulfate and osteopontin expression in angiotensin II-dependent left ventricular hypertrophy. Am. J. Hypertens. 15, 644-652

Sanguinetti M. C. (2002): Reduced transient outward $\mathrm{K}^{+}$current and cardiac hypertrophy. Causal relationship or epiphenomenon? Circ. Res. 90, 497-499

Smith G. (2007): Matters of the heart: the physiology of cardiac function and failure. Exp. Physiol. 92, 973-986

Tomaselli G. F., Marban E. (1999): Electrophysiological remodeling in hypertrophy and heart failure. Cardiovasc. Res. 42, $270-283$
Wolk R. (2003): Calcineurin, myocardial hypertrophy, and electrical remodeling. Cardiovasc. Res. 57, 289-293

Xu H., Dixon J. E., Barry D. M., Trimmer J. S., Merlie J. P., McKinnon D., Nerbonne J. M. (1996): Developmental analysis reveals mismatches in the expression of $\mathrm{K}^{+}$channel $\alpha$-subunits and voltage-gated $\mathrm{K}^{+}$channel currents in rat ventricular myocytes. J. Gen. Physiol. 108, 405-419

Yu H., Gao J., Wang H., Wymore R., Steinberg S., McKinon D., Rosen M. R., Cohen I. S. (2000): Effects of the reninangiotensine system on the current Ito in epicardial and endocardial ventricular myocytes from the cannine heart. Circ. Res. 86, 1062-1068

Zhao Y., Bader M., Kreutz R., Fernandez-Alfonso M., Zimmermann F., Ganten U., Metzger R., Ganten D., Mullins J. J., Peters J. (1993): Ontogenetic regulation of mouse Ren-2d renin gene in transgenic hypertensive rats, TGR(mREN2)27. Am. J. Physiol. 265, E699-707

Zolk O., Quattek J., Seeland U., El-Armouche A., Eschenhagen T., Böhm M. (2002): Activation of the cardiac endothelin system in left ventricular hypertrophy before onset of heart failure in TG(mREN2)27 rats. Cardiovasc. Res. 53, 363-371

Zhou C., Ziegler C., Birder L. A., Stewart F. R., Levitan E. S. (2008): Angiotensin II and stretch activate NADPH oxidase to destabilize cardiac Kv4.3 channel mRNA. Circ. Res. 98, 1040-1047

Received: August 27, 2008

Final version accepted: November 13, 2008 